\title{
Profitability Analysis and Marketing Efficiency of Soyabean (Glycine max) Value Chain among Actors in Abuja, Nigeria
}

\section{Olugbenga Omotayo Alabi ${ }^{*}$, Ayoola Olugbenga Oladele ${ }^{2}$ and Ibrahim Maharazu ${ }^{3}$}

${ }^{1}$ Department of Agricultural-Economics, University of Abuja, PMB 117 Gwagwalada-Abuja, Nigeria; ${ }^{2}$ Department of Agricultural Extension and Management, Federal College of Forestry Mechanization PMB 2273, Afaka, Kaduna, Nigeria; ${ }^{3}$ Directorate of University Advancement, Kaduna State University (KASU), PMB 2339, Kaduna, Nigeria.

Abstract | This study analyzed profitability and marketing efficiency of soyabean (Glycine max) value chain among actors in Abuja, Nigeria. This study was designed specifically to achieve the following objectives: describe the socio-economic characteristics of soyabean marketers, determine the marketing cost, marketing margin, and marketing efficiency of soyabean, analyze the costs and returns of marketing soyabean, evaluate factors influencing or affecting marketing efficiency of soyabean, and identify problems or constraints influencing marketing of soyabean. Data obtained were collected from one hundred and fifty (150) randomly selected soyabeans marketers, using well- structured, well-designed questionnaire. Data obtained were coded, analyzed using descriptive statistics, gross margin analysis, financial analysis, marketing margin, marketing efficiency, Probit model analysis, five point Likert scale and principal component analysis. The results revealed that most (86.33\%) of the soyabean marketers were between the ages of $31-60$ years, about $83.33 \%$ of soyabean marketers had less than 5 years marketing experiences. Cost of transportation constitutes $47.56 \%$ of the total variable cost. Estimated costs and returns analysis gave the gross margin and gross income of $\mathbb{N} 15,513,400$ and $\mathrm{N} 16,249,000$ per annum respectively. Estimated marketing margin and marketing efficiency were 20.13, and 338.66 respectively. Operating ratio (OR), rate of return on investment (RORI), and gross margin ratio (GMR) gave an observed values of $0.05,19.74$ and 0.95 , respectively. The gross margin ratio (GMR) of 0.95 means that for every one (1) naira invested in marketing of soyabeans, 95 kobo covered taxes, expenses, profits, and depreciation. Factors statistically and significantly influencing market efficiency of soyabeans were: gender $(\mathrm{P}<0.05)$, marital status $(\mathrm{P}<0.01)$, household size $(\mathrm{P}<0.01)$, level of education $(\mathrm{P}<0.01)$, and contact with extension agent $(\mathrm{P}<0.05)$. Problems or constraints facing marketers of soyabeans were: sales price instability, high cost of transportation, storage problems, lack of credit facilities, and bad road infrastructures. The retained components observed explained $93.24 \%$ of the variations in the component retained in the principal component model. The study recommends that marketers should develop new marketing strategies that will increase their profit margin. The sales price instability as a result of poor marketing arrangement could be addressed if processing firms were linked to soyabeans marketers and there is the need for mobilization of soyabean marketers to form group marketing, this will enable them to undertake bulk purchases, and arrange for common transportation mechanism. This may reduce high cost of transportation of their stock from farm gate to the market.

Received | June 23, 2020; Accepted | August 18, 2020; Published | October 07, 2020

*Correspondence | Olugbenga Omotayo Alabi, Department of Agricultural-Economics, University of Abuja, PMB 117 Gwagwalada-Abuja, Nigeria; Email: omotayoalabi@yahoo.com

Citation | Alabi, O.O., A.O. Oladele and I. Maharazu. 2020. Profitability analysis and marketing efficiency of soyabean (Glycine max) value chain among actors in Abuja, Nigeria. Sarbad Journal of Agriculture, 36(4): 1010-1019.

DOI | http://dx.doi.org/10.17582/journal.sja/2020/36.4.1010.1019

Keywords: Profitability, Marketing efficiency, Probit model, Principal component analysis, Soyabeans, Nigeria

December 2020 | Volume 36 | Issue 4 | Page 1010 
Introduction

Soyabean (Glycine max (L) Merrill) belongs to the family Leguminacea, is considered as one of the most important source of oil and protein. Soyabean is regarded as the most important source of oil and protein in the world. It contains about $40 \%$ protein which is ranked highest among plant protein sources, and $20 \%$ which is very rich in essential fatty acids devoid of cholesterol (Tiamiyu and Idowu, 2001). The nutritional quality of soybean is attributed to the distribution of amino acids which makes it nearly as good as meat. Soyabean is also rich in calcium, iron and vitamin. Apart from the $90 \%$ soybean oil that is used in the preparation of edible products like salad, margarine and cooking oil, the remaining $10 \%$ is used for the production of soaps, paint, printing inks and rubber substitute. It is also an export crop in most producing nations. Nigeria is reported to be the world's largest producer of soybean (Glycine max L.) which is used for food in the West, and also Central Africa (Root and Jacob, 1987), Nigeria was ranked the largest producer of soybean in Africa (IDRC, 2003) .It is a high valued crop grown for its protein, edible oil, livestock feed, soil replenishment and very recently as bio-diesel which offers a renewable and more environmental friendly alternative option of fossil fuel (Myaka et al., 2005; Olatunji et al., 2011). In addition, the bean is rich in vitamins, minerals and acids. Nigeria produces 850,000 metric tons per year which is still insufficient to satisfy domestic demand to attenuate soybean importance (Chianu et al., 2009). Soybean has been used as food for centuries because of its good nutritive value. Africa's malnutrition is a serious issue in terms of protein deficiency, an alternative source of high quality cheap protein was sought for, and soyabean was found to have the potentials to meet part of this need. It is widely believed that rural farmers have not yet been made to harvest the benefits of soyabean production on economic scale. Their individual smallness is a limiting factor for a better marketing and utilization of the crop, these problems and many more can cause or force farmers to use primitive tools thus posing as a strong barrier to an increased production. A properly functioning market is generally understood as the best organizational structure to achieve more efficient production and consumption decisions. The marketing system for soyabean has been charged as inefficient with poor marketing prices, as well as high marketing costs, while most rural farmers complained that they were ready to produce soybeans but to whom do they sell their soybeans to, as they need good pricing arrangements that do not work against them (Odeh, 2012). Marketing can be defined to be all activities that were involved in moving products (soyabeans) from producers to the consumers. This activity involves exchange activities, buying and selling, physical activities which were all designed to give the soyabeans products increased time utility, place utility and form utility and also the auxiliary activities which include financing, risk bearing activities and disseminations of information to actors (participants) in the soyabeans marketing process. Agricultural marketing encompasses activities that happen between the farm gate and the consumer, including food processing. The term supply chain analysis otherwise called value chain analysis can be defined to be groups of economic agents which can be a physical person, a farmer, or a trader also a consumer, in addition can be legal entities which include, a business, an authority or a development organization which contributes directly to the determinations of a final soyabean product. Thus, the value chain encompasses the complete or total sequence of operations or activities starting from the raw material, or an intermediate product, finishes downstream, after undergoing several stages of transformations or increases in value, at one stage or several final products at the level of the consumer (FAO, 2005). A more appropriate terminology for market chain is value chain. It refers to the full ranges of economic or physical activities needed to bring a product or a service right from conception stage, through production stage and delivery to final consumers. A broader system approach looks of activities implemented by various participants' actors, from primary producers, through harvesters, to processors, then traders, through service providers and up to upstream suppliers to the downstream customers. Value chain analyses contain issues which include organizational, coordination, powers relationship between participants' actors, linkages, and governance aspects. The value chain approach has been observed to be a very useful analytical tool for taking a more critical and objective looks at an organization position in a market.

\section{Objectives of the study}

The broad objective was to evaluate or analyze profitability and marketing efficiency of soyabean (Glycine max) value chain among actors in Abuja, 
Nigeria. Specifically, the study was designed to achieve the following objectives:

(i) describe the socio-economic characteristics of soyabean marketers; (ii) determine the marketing costs, marketing margin, and marketing efficiency of soyabean; (iii) analyze the costs and returns of marketing soyabean; (iv) evaluate factors influencing market efficiency of soyabean among actors; (v) identify the problems or constraints influencing marketing of soyabean.

\section{Justification of the study}

Performance of soyabean marketing can be improved and this requires appropriate planning, proper knowledge and behaviours of the various actors involved in the marketing system. Marketing is expected to provide access to farm inputs, information on marketing and markets, farm best practices of agricultural produce, appropriate pricing, and access to farm inputs to transform the soyabean markets (Abah et al., 2015a). Inability to achieve self-sufficiency in production can be attributed to inefficiency in soyabean marketing in the nation. Information on soyabean marketing would further generate interest in agricultural produce marketing and help policy decision makers to re-examine, reevaluate or re-appraise government position on food sufficiency and marketing in Nigeria. Empirical findings on soyabean production and marketing will provide information to government, policy makers, researchers, stakeholders, development partners that will be very useful for economic development. The role or importance of marketing in economic development can be explained on the fact that without efficient marketing system, the farmers will not be encouraged or inclined to produce more and increase production. According to Olukosi et al. (2012) if the marketing system does not serve the goal, interest, or motive and needs of the farmers who are the producers, or rather if the production from farmers do not move to market and bring profits or additional earnings to the farmers, the farmer will not be encouraged or he or she will not be inclined to increase his production. The price system, together with competition gives the mechanism both for coordinating the flow of resources into production and also the flow of goods and services necessary for its use. Within the system of marketing there are activities such as distributions of income, resources that will be allocated, prices of commodities, and formation of capital that are determined.

\section{Materials and Methods}

\section{The study area}

The areas of study were the Gwagwalada and Kwali Area Councils, Abuja, Nigeria. Gwagwalada is an area council located at Latitudes 80 55' 59" North of the Equator and Longitudes 70 5'59" East of the meridian. Kwali Area Council is about $13.5 \mathrm{Km}$ away from it. The study areas were characterized by high humidity, which has a heat trap effect. There are notably two main seasons; the wet and dry. Annual rainfall, ranges from $1100 \mathrm{~mm}$ to $1700 \mathrm{~mm}$. The climatic condition of the study area permits agricultural activities such as cultivation of crops, grazing of animals and fishery production. Gwagwalada Area Council has a total land mass of about 1,043 Square Kilometer and with a population of 157,770 people (NPC, 2006). Average annual rainfall ranges from 800 to $1,500 \mathrm{~mm}$ and temperature ranges between $21^{\circ} \mathrm{C}-35^{\circ} \mathrm{C}$ Kwali Area council started operations in October 1996 together with Bwari Area council. The council is located in the South Western part of the Abuja and lies between Latitudes 8.9 degrees south and Longitudes 78 degrees east. The council has a total land area of about $1,700.400$ square kilometers. The observed population of the council is about 250,000 people (NPC, 2006). The people settled in disperse pattern, the settlement was in indigenous cluster type in: Kwali town, Yebu, Leda, Sheda,Dangana, Pai Ashara, Dabi. The major ethnic groupings were: Ganagana, Gbagis, Basa, Fulani, Hausa, and other ethnic groups.

\section{Sampling techniques and sample size}

The study employed and adopted multi-stage sampling technique. First stage, two area councils were selected through simple random sampling technique using ballot-box raffle draw method. Second stage, 8 wards were randomly selected in Gwagwalada Area Council using ballot-box raffle draw method, while 7 wards were randomly selected in Kwali Area Council using ballot-box raffle draw method. Thirdly, 8 villages were randomly selected in Gwagwalada Area Council using ballot-box raffle draw method, and 7 villages were randomly selected in Kwali Area Council using ballotbox raffle draw method. Fourth and final stage, 10 soyabean marketers were randomly selected per village from the two area council using ballot-box raffle draw method making a total sample size of 150 respondents.

\section{Method of data collection}

Cross-sectional data were employed. Questionnaire 
was the instrument employed for the study. Where necessary personal and group interview was included in situations where the respondents or marketers are not educated or instances of language barrier. The data obtained were: price of soybean supplied, quantity of soybean marketed, market information, gender, credit access, age, marketing experience, family size, type of marketing organization, educational level, and constraints to soybean marketing. Data on quantity of soybean sold, transportation and marketing costs were also being obtained and used to calculate marketing costs and marketing margins. Data on market information system, transport facilities, exchange and pricing arrangements, system of storage, purchasing energy, price setting initiatives or strategy, barriers to entry, capital and selling strategy, were also obtained from sample informants using the same questionnaire which was pretested and validated. Also, data were obtained on credit facilities, agricultural extension services, marketing informations, and institutional support activities.

\section{Method of data analysis}

The following statistical and econometrics tools were employed to achieve specific and broad objectives:

(i) Descriptive statistics, (ii) Gross margin analysis, (iii) Financial analysis, (iv) Marketing margin, (v) Marketing efficiency, (vi) Probit model analysis, (vii) Five point likert scale, and (viii) Principal component analysis.

\section{Descriptive statistics}

This involves or encompasses the use of frequency distributions, mean, and percentages. Descriptive statistics was used to have a summary statistics of data obtained from the field. This was specifically used to achieve objectives one (i), two (ii) and five (v) which identifies the socio-economic characteristics of soyabean marketers and constraints or problems facing soyabean marketers.

\section{Gross margin analysis}

Gross Margin Analysis is defined as the difference between the observed gross farm income (GFI) and total variable cost (TVC) (Olukosi and Erhabor, 2005). It was used to determine the potentials profitability of marketing soyabean. The tools were used to achieve specific objective three (iii).

Gross margin model (GM) is expressed as follows:

$$
G M=T R-T V C \quad \ldots(1)
$$

Where;

GM= Gross Margin ( $)$; TR= Total Value of Output or Total Revenue from the marketing soyabean ( $)$; TVC= Total Variable Cost ( $)$, and TR= P.Q(N).

Where: $-\mathrm{P}=$ Price of Soyabean Marketed in Naira per Kilogram, $Q=$ Output of Soyabeans Marketed in Kilogram.

Net Farm Income (NFI) is stated thus:

$$
N F I=\sum_{i=1}^{n} P_{1} Y_{i}-\sum_{j=i}^{m} P_{j} X_{j}-\sum_{k=1}^{k} G K
$$

$\mathrm{NFI}=$ Net Farm Income (Naira Per annum); $\mathrm{P}_{\mathrm{i}}=$ Unit Price of Product (Naira/Unit); $\mathrm{P}_{\mathrm{j}}=$ Price per Unit Variable Input (Naira/Unit); GK= Cost of all Fixed Inputs (where $\mathrm{k}=1,2,3, \ldots \mathrm{k}$ fixed input); $\Sigma=$ Summation or Addition signs.

This was used to achieve part of specific objective three (iii)

\section{Financial analysis}

Gross Margin Ratio (GMR) following Ben-Chendo (2015) was used to determine the profitability of marketing soyabean. This was used to achieve part of specific objective three (iii).

$$
\text { Gross Margin Ratio }=\frac{\text { Gross Margin }}{\text { Total Revenue }}
$$

In order to evaluate the strength and financial positions of soybean marketing enterprises, operating ratio and rate of return per naira invested were considered. An operating ratio (OR) according to Olukosi and Erhabor (2005) is stated thus:

$$
O R=\frac{T V C}{G I}
$$

Where;

$\mathrm{OR}=$ Operating Ratio (Units); TVC $=$ Total Variable Cost (Naira); GI= Gross Income (Naira).

An Operating Ratio (OR) that is less than one (1) implies that the total revenue obtained from soyabeans marketing was able to pay for the cost of variable inputs used in the enterprise (Olukosi and Erhabor, 2005). The rate of return per naira invested (RORI) in soybean marketing is stated thus: 


$$
R O R I=\frac{N I}{T C}
$$

Where,

RORI= Rate of Return per Naira Invested (Units); $\mathrm{NI}=$ Net Income from Soyabeans Marketing (Naira); $\mathrm{TC}=$ Total Cost (Naira).

The financial analysis was used to achieve part of specific objective three (iii)

\section{Marketing margin}

Marketing Margin is defined as the difference between cost to the seller and the cost to the consumers. It also represents payments for activities such as assembling, processing, transporting, and retailing charges added to the farm products. Marketing Margin was computed using the formular:

$$
\text { Marketing Margin }=\frac{\text { Selling Price }- \text { Supply Price }}{\text { Selling Price }} \times 100
$$

The marketing margin was used to achieve part of specific objective three (iii)

\section{Marketing efficiency}

The coefficients of marketing efficiency can be simply expressed as the difference between total sales revenue (TR), and total cost (TC) divided by total cost (TC) incurred. The model is specified as:

$$
\text { Marketing Efficiency }=\frac{\mathrm{TR}-\mathrm{TC}}{\mathrm{TC}} \times 100
$$

Marketing Efficiency was used to achieve part of specific objective three (iii).

\section{Probit model analysis}

A Probit model following Alabi et al. (2014) was used. Probit model is stated as:

$$
Z_{i}=\beta_{0}+\beta_{1} X_{1}+\beta_{2} X_{2}+\beta_{3} X_{3}+\beta_{4} X_{4}+\beta_{5} X_{5}+\beta_{6} X_{6}+\beta_{7} X_{7}+\beta_{8} X_{8}+U_{i}
$$

Where,

$Z_{i}=$ Marketing Efficiency (1, if ME $>1 ; 0$, Otherwise); $\mathrm{i}=$ Number of Independent Variables; $\beta_{0}=$ Constant Term; $\beta_{1}-\beta_{8}=$ Regression Coefficients; $\mathrm{X}_{1}=$ Gender (1, Male; 0, Otherwise); $X_{2}=$ Age (Years); $X_{3}=$ Marital Status (1,Married; 0, Otherwise); $\mathrm{X}_{4}=$ Household Size (Total Number of Person); $\mathrm{X}_{5}=$ Level of Education (0, Non-Formal; 1, Primary; 2, Secondary; 3, Tertiary);
$\mathrm{X}_{6}=$ Membership of Cooperative Organization (1, Membership; 0, Otherwise); $\mathrm{X}_{7}=$ Access to Credit (1, Access; 0, Otherwise); $\mathrm{X}_{8}=$ Contact with Extension Agent (1, Contact; 0, Otherwise); $\mathrm{U}_{\mathrm{i}}=$ Error Term.

\section{Five point likert-scale}

To ascertain the perceptions of soyabean marketers, problems and constraints faced by soyabean marketers, Five-Point Likert- scale was used. To ascertain soyabean marketer's perceptions, the response options and values assigned were as follows: strongly agree $=$ 5 ; agree $=4$; undecided $=3$, disagree $=2$, and strongly disagree $=1$. These values were added and divided by 5 to obtain 3.0, which was observed and regarded as the mean. Perceptions, or problems with mean scores (MS) greater than or equal to 3.0 was regarded as "Significant" while perceptions, or problems with mean responses lower than 3.0 was regarded as "NonSignificant". The mean scores for this study was calculated using the formula below:

$$
M S=\frac{\sum[R P \times 0]}{\sum F}
$$

Where, MS= Mean Score (Units); RP= Rating Point (Units); $\mathrm{O}=$ Observation (Units); $\Sigma \mathrm{F}=$ Total Number of Sampled Respondents (Units).

This was used to achieve part of specific objective five (v).

\section{Principal component analysis (PCA)}

The perceived constraints or problems faced by soybean marketers were analyzed using principal component analysis (PCA). The Model of Principal Component $(\mathrm{PCA})$ is stated thus:

$$
\begin{gathered}
x=x_{1}, x_{2}, x_{3}, \ldots, x_{p} \ldots(10) \\
\propto_{k}=\propto_{1 k 1}, \propto_{2} K, \propto_{3} k, \ldots, \propto p k \\
\propto_{K}^{T} x=\sum_{j=1}^{p} \propto_{k j X j} \ldots(11) \\
\text { Var }=\left[\propto_{K}^{T} X\right] \text { is Maximum }
\end{gathered}
$$

Subject to

$$
\begin{gathered}
\propto_{K}^{T} \propto_{K}=1 \quad \ldots(14) \text { and } \\
\operatorname{Cov}=\left[\propto_{1}^{T} \propto-\propto_{2}^{T} \propto\right]=0 \quad \ldots(15)
\end{gathered}
$$




$$
\begin{aligned}
& \operatorname{Var}\left[\propto_{k} X\right]=\lambda_{k} \\
& S=\frac{1}{n-1}(X-\bar{X})(X-\bar{X})^{T} \\
& S_{i}=\frac{1}{n-1} \sum_{i=1}^{n}\left(X_{i}-\bar{X}_{i}\right)\left(X_{I}-\bar{X}_{i}\right)
\end{aligned}
$$

Where,

$\mathrm{X}=$ vector of 'P' Random Variables; $\alpha_{\mathrm{k}}=$ Vector of 'P' Constraints; $\lambda_{k}=$ Eigen value; $T=$ Transpose; $S=$ Sample Covariance Matrix.

This was used to achieve specific objective five (v).

\section{Results and Discussion}

Socio-economic characteristics of soybean marketers Table 1 observed that about $86.33 \%$ of respondents fell within the age group of 31-60 years. This means that soybeans marketers were still active and young. This agrees or this is in consonance with the findings of Alabi et al. (2013), Bakoji et al. (2013). Age is observed to be important determining factor of socio-economic status of a population, since people can wears and loss of energy strength as they advanced in age. About $51.33 \%$ of soybeans marketers were male. This agrees or is in line with the findings of Alabi and Ibraheem (2018), Jibril et al. (2007). Majority (90\%) of the soybeans marketers were married. Illiteracy is one of the factors working against agricultural development in Nigeria. As shown in Table 1,55.34\% of the soybeans marketers had formal education, this agrees or is in line with earlier reports of Alabi and Alabi (2002), Bakoji et al. (2013). However, $44.66 \%$ of the respondents had no formal education. Years of marketing experience of soybeans marketers observed that $83.33 \%$ of the marketers had less than 5 years of marketing experiences, this agrees or is in line with the findings of Alabi (2012),Jibril et al.(2007).The household sizes were large, about $80.67 \%$ of the soybean marketers had less than 10 members in their household, this means that the marketers had enough family labour that maybe utilized in their soybeans marketing activities which is in view with Alabi et al. (2014), Abdu (2012). However, only $19.33 \%$ had between 11-20 members as household size.
Table 1: Socio-economic profiles or characteristics of soybean marketers.

$\begin{array}{lll}\text { Variable } & \text { Frequency } & \text { Perce } \\ \text { Age (Years) } & & \\ 10-20 & 01 & 0.67 \\ 21-30 & 13 & 8.67 \\ 31-40 & 62 & 41.33 \\ 41-50 & 48 & 32.00 \\ 51-60 & 20 & 13.00 \\ 61-70 & 05 & 03.00 \\ 71-80 & 01 & 0.67\end{array}$

Sex

Male $\quad 77 \quad 51.33$

$\begin{array}{lll}\text { Female } & 73 & 48.67\end{array}$

Marital status

$\begin{array}{lll}\text { Married } & 135 & 90.00 \\ \text { Single } & 07 & 04.67 \\ \text { Divorced } & 04 & 02.67 \\ \text { Widow } & 04 & 02.67\end{array}$

Education level

Secondary $\quad 40 \quad 26.67$

Tertiary $\quad 09 \quad 06.00$

Non-Formal $\quad 67 \quad 44.66$

Marketing experience (Years)

$\begin{array}{llll}1-5 & 125 & 83.33 & 3.83 \\ 6-10 & 25 & 16.67 & \\ \text { Household size (Units) } & & & \\ 1-10 & 121 & 80.67 & 7.4 \\ 11-20 & 29 & 19.33 & \\ \text { Total } & 150 & 100.00 & \end{array}$

Source: Field survey (2019), Computed using STATA Version14.

\section{Analysis of costs and returns of soybeans marketing}

Table 2 presented the marketing costs, marketing margin and marketing efficiency of soybeans marketing. The cost of storage constitutes $9.38 \%$ of the total variable cost (TVC) for soybean marketing, the transportation cost constitutes $47.56 \%$, the cost of labour and cost of loading/offloading constitutes $28.76 \%$, and $14.30 \%$ of the total variable cost (TVC) respectively. This agrees or is in consonance with the findings of Alabi and Ajooku (2012), Alabi et al. (2009), Abdu (2012). The total variable cost (TVC) was $\$ 735,600$ while, the gross income (GI) of the soyabean marketers was $\$ 16,249,000$ with the gross margin of $¥ 15,513,400$. This shows that soybean marketing was profitable with marketing margin of $20.13 \%$ and marketing efficiency of $338.66 \%$. The 
result agrees or is in accordance with the findings of Alabi et al. (2010), Jibril et al. (2007). The operating ratio and rate of return on investment were 0.05 , and 19.74 , respectively. The gross margin ratio was 0.95 . This means that for every one (1) naira invested in soybean marketing, 95 kobo covered taxes, expenses, profits, and depreciation. This agrees with findings of Alabi and Ibraheem (2018), and Alabi et al. (2014).

Table 2: Costs and returns analysis of soybeans marketing.

$\begin{array}{ll}\text { Item } & \text { Value (Naira) } \\ \text { Variable cost } & \\ \text { Cost of storage } & 2,250 \\ \text { Cost of labour } & 234,650 \\ \text { Cost of transportation } & 388,000 \\ \text { Cost of load/Offload } & 110,400 \\ \text { Total variable cost } & 735,600 \\ \text { Returns } & \\ \text { Gross income } & 16,249,000.00 \\ \text { Gross margin } & 15,513,400.00 \\ \text { Marketing cost } & 735,600.00 \\ \text { Marketing margin (\%) } & 20.13 \\ \text { Marketing efficiency (\%) } & 338.66 \\ \text { GMR } & 0.95 \\ \text { OR } & 0.05 \\ \text { RORI } & 19.74\end{array}$

Source: Field Survey (2019), Computed Using STATA Version 14.

Factors infuencing marketing efficiency of soyabeans

Maximum Likelihood Estimates (MLE) of the Probit Model presented in Table 3 shows that out of the eight (8) independent or explanatory or exogenous or explanatory variables included in the Probit model, the coefficients of gender $(\mathrm{P}<0.05)$, marital status $(\mathrm{P}<0.01)$, and household size $(\mathrm{P}<0.01)$, level of education $(\mathrm{P}<0.01)$, and contact with extension agent $(\mathrm{P}<0.05)$ were the significant variables or factors influencing marketing efficiency of soyabeans. The results of marginal effect of the Probit model were also presented in Table 3. It should be noted and observed that a positive sign on a parameter estimates indicate that higher values of the variable tend to increase the probability or likelihood of marketing efficiency. Similarly, a negative sign of coefficient means decrease relationship, hence higher or additional value of variables or factors would decrease the probability of marketing efficiency. Maximum Likelihood Estimate shows that the Log Likelihood was -107.89921 , while Chi-Square values was 67.78 and were significant at $1 \%$ levels of probability. This means that the overall effect of the explanatory or independent variables were statistically significant. The coefficient of determinations (Pseudo R Square) was 0.5413 (54.13\%). This means that $54.13 \%$ of the variations in the dependent or explained variable which is the marketing efficiency were explained by the explanatory or independent or exogenous variables included in the regression model. However, as observed in Gujarati and Porter (2009), models with binary dependent variables, the goodness of fit can be of secondary issue or importance. What matters were the signs associated with regression parameters or coefficients and their statistical and/or practical significance. The fitted equation for Probit regression model is stated as: $\mathrm{Z}=0.1513+0.0216 \mathrm{X}_{1}+0.3191 \mathrm{X}_{2}+0.1481 \mathrm{X}_{3}+0.1262 \mathrm{X}_{4}+0.1862 \mathrm{X}_{5}$
$+0.0676 \mathrm{X}_{6}+0.003151 \mathrm{X}_{7}+0.4512 \mathrm{X}_{8} \ldots(18)$

Level of education had positive coefficient and was significant statistically at $1 \%$ probability level. This means that a unit (1) increase in level of education will result to about 0.1669 marginal increases in marketing efficiency of soyabeans. These observations mean as soyabeans marketers get educated it is expected that they will be better informed about cost saving strategies. Also, as marketers increase their education status they will save more and understand more about marketing strategies, market structure, conduct and pricing strategies. This result agrees or is in line with findings of Alabi (2012) and Alabi et al. (2013). The coefficient of household size of the soyabean marketers measured was positive and statistically significant at $1 \%$ level of probability. The result implies that household size was a significant factor that influences marketing efficiency of the soyabeans. An increase in household size lead to a reduction in the marketing efficiency with a marginal effect of 0.0371 . The more the household size the more efficient the marketers are expected to be. This is in conformity with the apriori expectations because household member in African setting act as additional labour source for farming and marketing activities. This result agrees with the findings of Alabi et al. (2010). The coefficient of age was observed to be positive and statistically significant at $5 \%$ probability level with a marginal increase of 0.067 in the marketer efficiency. This implies that efficiency of the trader increases with age i.e. as soyabean marketers advanced in age, the marketers becomes more efficient. 
Table 3: Factors influencing marketing efficiency of soyabeans.

$\begin{array}{lllll}\text { Variables } & \text { Coefficient } & \text { Standard error } & \text { z-Score } & \text { Marginal effect } \\ \text { Gender }\left(\mathrm{X}_{1}\right) & 0.0216218 & 0.0134124 & 2.4^{* *} & 0.0167 \\ \text { Age }\left(\mathrm{X}_{2}\right) & 0.3191751 & 0.3761918 & 1.21 & 0.1026 \\ \text { Marital status }\left(\mathrm{X}_{3}\right) & 0.1481626 & 0.042156 & 5.3^{* * *} & 0.0419 \\ \text { Household size }\left(\mathrm{X}_{4}\right) & -0.1216223 & 0.01812676 & 4.16^{* * * *} & -0.0371 \\ \text { Level of education }\left(\mathrm{X}_{5}\right) & 0.1862245 & 0.2523579 & 3.28^{* * *} & 0.1669 \\ \text { Member of cooperatives }\left(\mathrm{X}_{6}\right) & 0.0676706 & 0.304458 & 0.75 & 0.0202 \\ \text { Access to Credit }\left(\mathrm{X}_{7}\right) & 0.031572 & 0.331465 & 0.01 & 0.0003 \\ \text { Contact with extension agents }\left(\mathrm{X}_{8}\right) & 0.4741 & 0.7181213 & 2.43^{* *} & 0.1413 \\ \text { Constant } & 0.1513 & 0.6132 & 2.43^{* *} & \end{array}$

Chi2: 67.78; Pseudo R2: 0.5413; Log Likelibood: -107.89921. **: Significant at Probability< 0.05; ***: Significant at Probability < 0.01. Source: Field Survey (2019), Computed Using STATA Version 14.

Soyabean marketers who have advanced in age with more experience will be able to take more discrete decisions and read the market situations better.

\section{Principal component analysis (PCA) of constraints facing soyabeans marketers}

Table 4 shows the results of the constraints or problems facing soyabeans marketers. PCA can be defined as a statistical applications or techniques that transforms interrelated data with many variables into few and small numbers which were uncorrelated variables. From the result, the number of principal components retained using the Kaiser Meyer criterion were five (5) based on the Eigen value greater than 1. The retained components observed explained 93.24\% of the variations of the components included in the model. The Kaiser-Meyer-Olkin which measures sampling adequacy (KMO) gave an estimated value of 0.64 and the Bartlett test of sphericity of 2071.002 was observed to be significant at $1 \%$ (one percent) level of probability, and this demonstrated the feasibility of using the data set for factor analysis. Sales price instability had an Eigen value of 3.48831 and it was ranked $1^{\text {st }}$ in the order of importance based on perceptions of the soyabean marketers. High cost of transportation, and storage problems with Eigen values of 2.86434 and 1.5432 were ranked $2^{\text {nd }}$ and $3^{\text {rd }}$ respectively in the order of occurrence based on the perceptions of soyabean marketers as the major problems or constraints facing soyabean marketers. Also, lack of credit facilities and bad roads with Eigen values of 1.33328 and 1.05174 were ranked $4^{\text {th }}$ and $5^{\text {th }}$ in order of their occurrence and importance respectively based on the perceptions of soyabeans marketers as other problems or challenges faced by the industry.
Table 4: Results of the principal component analysis of constraints or problems facing soyabean marketers.

\begin{tabular}{lllll} 
Constraints eigen & $\begin{array}{l}\text { Eigen- } \\
\text { Value }\end{array}$ & $\begin{array}{l}\text { Differ- } \\
\text { ence }\end{array}$ & $\begin{array}{l}\text { Propor- } \\
\text { tion }\end{array}$ & $\begin{array}{l}\text { Cumu- } \\
\text { lative }\end{array}$ \\
Sales price instability & 3.48831 & 0.46516 & 0.3723 & 0.3723 \\
$\begin{array}{l}\text { High cost of transpor- } \\
\text { tation }\end{array}$ & 2.86434 & 1.2776 & 0.2476 & 0.6199 \\
\hline Storage problems & 1.57432 & 0.364165 & 0.1178 & 0.7377 \\
Lack of credit facilities & 1.33328 & 0.26231 & 0.1239 & 0.8616 \\
Bad road Infrastructure & 1.05174 & 0.24072 & 0.0708 & 0.9324 \\
\hline
\end{tabular}

Source: Field Survey (2019) using STATA Version 14. Bartlett test of sphericity KMO: 0.640; Chi-Square: 2071.002**w; Rho: 1.0000

\section{Conclusions and Recommendations}

Soyabean marketers are young, energetic and resourceful. The mean age of soyabean marketers was 41 years. Soyabean marketers had an average of 4 years experiences in soyabean marketing. The household sizes were large, on the average, soyabean marketers had 7 people per household. The total soyabean marketing cost was 735,600 Naira. The marketing margin and marketing efficiency for soyabean were $19.74 \%$ and $338.66 \%$, respectively. The gross margin ratio, rate of return on investment, and operating ratios of soyabean marketing were $0.95,21.08$ and 0.05 respectively. The gross income and gross margin of marketing soyabeans were 16, 249,000 Naira and $15,513,400$ Naira respectively. The results observed and presented confirmed that marketing of soyabeans is profitable and efficient. Gender, household size, marital status, level of education, and contact with extension agents were statistically significant factors or variables influencing marketing efficiency of soyabeans. Soyabeans marketers were faced with major constraints of sales price instability, high cost 
of transportation due to poor roads networks, lack of credit facilities and also storage problems.

The following under-listed points in terms of policy recommendations were made:

1. Policies and programmes should be put in place by government at all levels to make sure that efficient and most effective marketing system of agricultural commodities including soyabean that will guarantee availability, accessibility and affordability should be appropriately put in place.

2. Government, private organizations, and development partners should formulate appropriate policies and programmes to encourage large scale enterprises

3. Agricultural programmes by government and relevant agencies should be targeted towards youth participation in agriculture including marketing of agricultural produce. Youth in marketing agricultural produce should form relevant cooperatives, this will enable them have access to credit facilities, research findings, new innovations, farm inputs and markets. Agricultural cooperative members could easily market their produce.

4. Government and development partners should provide continuous extension services and training on market, packaging, storing, grading, proper handling for actors along the soyabean value chain.

5. Government should embark on massive construction and maintenance of feeder road, rural to urban and rural to rural feeder roads infrastructures. This will enable marketers evacuate agricultural produce from farms to markets. Market stalls, equipments, banking services, fire and security services, health facilities, electricity, and water supply should be provided in the market.

6. Soyabean marketers should develop new marketing strategies that will increase their profit margin.

7. Appropriate sales policies should be put in place by government. Sales price instability as a result of poor marketing arrangement could be addressed if processing firms are linked to soybeans marketers.

8. There is need for mobilization of soybean marketers into group marketing for them to be able to undertake bulk purchase and arrange for common transportation mechanism. This may reduce high cost of transportation of their stock from farm gate to the market.

Extension officers should be employed for transfer of new research findings on soyabean value chain to farmers and marketers.

\section{Novelty Statement}

Examining factors influencing marketing efficiency of soyabeans value chain among actors and the use of principal component analysis on constraints facing soyabeans actors or marketers added more innovations to the research article.

\section{Author's Contribution}

Alabi, O.O, Oladele, A.O and Maharazu, I, jointly design the research article, administered the questionnaire, code, analyze data, interpret research results, and jointly write research report.

\section{Conflict of interest}

The authors have declared no conflict of interest.

\section{References}

Abah, D.A., A.G. Anjeinu and A.P. Iorhon. 2015a. Analysis of the structure and conduct of paddy rice marketing in Benue State, Nigeria. Am. J. Market. Res., 1(2): 70-78.

Abdu, Z., 2012. Profitability of soybeans marketing in the guinea Savanah zone of Nigeria. 7 Savannah J. Agric., 1: 88-92.

Alabi, O.O., A.A.A. Coker and M.E. Idegbesor. 2013. Net farm income analysis of maize production in gwagwalada area council of federal capital territory, Nigeria. J. Agric. For. Soc. Sci., 11(1): 166-182. https://doi.org/10.4314/joafss. v11i1.17

Alabi, O.O. and O.A. Alabi. 2002. Economics of cassava production in Kogi State: A case study of Yagba East Local Government Area. Savannah J. Sci. Agric., 1(1): 105-110.

Alabi, O.O., C.T. Efunnuga, S. Omodona and A.F. Lawal. 2009. Factors influencing gross income from cassava processing in Ikenne local Government area of Ogun State. Int. J. Sustainable Dev., 6(2): 59-65.

Alabi, O.O., M.U. Amadi and T.S. Ijir. 2014. Determinants of gross income among smallscale sorghum producers in Gwagwalada area council 
of the federal capital territory (FCT) Abuja, Nigeria. Agric. Econ. Ext. Res. Stud., 3(1): 1626.

Alabi, O.O., A.A. Coker, S.S. Adeola and I. Maduekwe. 2010. Technical efficiency in sesame production in Nassarawa Doma Local Government Area of Nassarawa State, Nigeria: An application of stochastic frontier model. Int. J. Agric. Rural Dev., 1(2): 115-121.

Alabi, O.O., A.O. Ayoola and H. Saidu. 2010. Resource-use efficiency and economies of scale of maize-rice intercropping mixture in Bosso Local Government Area of Niger State, Nigeria. Int. J. Agric. Rural Dev., 1(2): 147-152.

Alabi, O.O., A.F. Lawal, Y.A. Awoyinka and A.A. Coker. 2014. Probit model analysis of smallholder farmers decision to use agrochemicals inputs in federal capital territory Abuja, Nigeria. Turkey Int. J. Food Agric. Econ. Nigde Univ. Turkey. 2(1): 85-93. https://doi. org/10.5897/JAERD2013.0536

Alabi, O.O., 2012. Profitability analysis of maize and sorghum production among cooperative societies' farmers in Gwagwalada and Kwali Area Councils of FCT, Abuja, Nigeria. Benin Int. J. Agric. Econ. Ext. Ser. 2(1): 8-14.

Alabi, O.O. and A. Ibraheem. 2018. Economics of maize (Zea mays) production in Igabi local government of Kaduna State, Nigeria. J. Agric. Fac. Gaziosmanpasa Univ., 35(3): 248-257. https://doi.org/10.13002/jafag4434

Alabi, O.O. and H.A. Ajooku. 2012. Socioeconomic factors influencing cassava production in Kuje and Abaji Area Councils of Federal Capital Territory, Abuja, Nigeria. J. Agric. For. Soc. Sci., 10(2): 73-84.

Bakoji, I., U. Haruna H.A. Danwanka and S.A. Jibril. 2013. Marketing Analysis of Soyabeans (Glycine max) in Toro LGA Bauchi State, Nigeria. Res. J. Agric. Environ. Manage., 2(11): 358-364.

Ben-Chendo, G.N., N. Lawal, M.N. Osuji, I.I. Osugiri and B.O. Ibeagwa. 2015. Cost and Returns of Paddy Rice Production in Kaduna State of Nigeria. Int.J. Agric. Market., 2(5): 84-
89.

Chianu, J.N., O. Ohiokpehai, B. Vanlauwe, A. Adesina, H. De. Groote and N. Singinga. 2009. Promoting a versatile but yet Mino crop: Soybean in the farming systems of Kenya. J. Sustainable Dev. Afr., 10(4): 1-21.

FAO, 2005. Technical compendium on composite flours. United Nation's economics commission for Africa, Addis Ababa. 45(3): 67.

Gujarati, D.N and Porter, D.C. 2009. Basic econometrics. 5th Edition, New York, Mc GrawHill/Irwin Publishers.

IDRC, 2003. International development research council, Canada.

Jibril, S.A., I. Muhammed, U.Haruna and G. Yamta. 2007. Economic analysis of soybean marketing in muda lawal market, Bauchi Metropolis, Bauchi State. pp. 70-82.

Myaka, F.A., G. Kirenga and B. Malema. 2005. Proceeding of the first national soybean stakeholders workshop, Morogoro, Tanzania. pp.10-11.

National Population Commission (NPC) 2006. Population census official gazette extraordinary, 94(24): May 15, Lagos, 2007.

Odeh, O., 2012. The return of soy miracle crop of our time. Dev. Comm. Netw., 2 http://:www. devcomsnetwork.org Retieved 24/12/2011

Olatunji, S.O., A.C. Agumagu and M.O. Adosogy. 2011. Utilization of soybeanm products by farm families in Abia State Nigeria. J. Agric. Ext. Rural Dev., pp. 186-192.

Olukosi, J.O., S.U. Isitor and M.O. Ode. 2012. Introduction to agricultural marketing and prices: Principles and applications. Living books series gu publications, Abuja, Nigeria.

Olukosi, J.O. and P.O. Erhabor. 2005. Introduction to farm management economics: Principles and applications. Agitab Publishers Limited, Zaria, Kaduna, Nigeria. pp. 77-83.

Root, A. and M.B. Jacob. 1987. A Soyabean Biotechnology Outlook. 6(2): 1-3.

Tiamiyu, I. and O. Idowu. 2001. Performance of rice market in Kwara State. J. Econ. Theory. 2(1): 22-23. 